\title{
ESTUDO DAS PERCEPÇÕES E DO COMPORTAMENTO DOS CONSUMIDORES DE GASOLINA EM UMA METROPÓLE BRASILEIRA
}

\author{
MOURA, Luiz Rodrigo Cunha Moura ${ }^{1}$ \\ BERNI, Murilo César de Azevedo Rabelo ${ }^{2}$ \\ CUNHA, Nina Rosa Silveira ${ }^{3}$ \\ MOURA, Luiz Eduardo Leite de $\mathrm{e}^{4}$
}

\begin{abstract}
RESUMO: O objetivo por meio desse trabalho é o de conhecer o comportamento de compra de gasolina por parte dos consumidores. Além disso, se buscou identificar quais são os atributos mais importantes em um posto de combustível, a percepção de riscos por parte dos consumidores e os fatores que afetam o seu comportamento. Em termos metodológicos, primeiramente foram realizados dois grupos de foco e seis entrevistas com consumidores e com profissionais de postos de combustíveis. Os resultados foram utilizados para a confecção dos questionários. Em seguida foi realizado um pré-teste para possíveis correções e cálculo da amostra, com 290 questionários válidos. Os resultados obtidos indicam que o quarteto "qualidade-rapidez-aparência-localização" são os fatores mais importantes para os consumidores de gasolina e que a maioria dos clientes somente abastece em um ou dois postos de combustível. Observou-se que os consumidores enxergam riscos ao comprar esse produto quando o combustível é muito barato, quando abastecem em um posto pela primeira vez, principalmente se for em rodovias e não em cidades. Não se obteve diferenças significativas entre homens e mulheres e nas conclusões são discutidas diversas ações e recomendações que podem ser tomadas pelos gestores do setor de combustíveis, notadamente em relação ao marketing.
\end{abstract}

Palavras-Chave: Comportamento do Consumidor. Atitudes. Posto de Combustível.

SUMMARY: The goal through this work is to understand the behavior of purchasing gasoline for consumers. In addition, we have tried to identify which are the most important attributes in a gas station, the perceived risks by consumers and factors that affect their behavior. In terms of methodology, were initially performed two focus groups and six interviews with consumers and gas stations professionals. The results were used to construct the questionnaires. Then we performed a pretest to possible corrections and calculation of the sample, with 290 valid questionnaires. The results indicate that the quartet "quality-speed-appearance-location" are the most important factors for consumers of gasoline and that most customers only caters to one or two gas stations. It was observed that consumers see risk to buy it when the fuel is very cheap when sourcing from a post first, especially if it is not on highways and in cities. The differences between men and women were not statistically significant and the findings are discussed several actions and recommendations that can be taken by the fuel sector managers, especially with respect to marketing.

Keywords: Consumer Behavior. Attitudes. Gas Station.

\footnotetext{
${ }^{1}$ Bacharel em Informática pela Universidade Federal de Viçosa - MG.Especialista em Tecnologia da Informação e Gestão Empresarial pela PUC - MINAS. Mestre em Administração pela UFMG. Doutor em Administração pela UFMG.Professor Adjunto do Centro Universitário UNA nas áreas de Marketing e Planejamento Estratégico.

${ }^{2}$ Bacharel em Administração - Centro Universitário UNA. Especialista em Marketing - Centro Universitário UNA.Mestre em Administração - FEAD. Professor do Centro Universitário Belo Horizonte.

${ }^{3}$ Bacharel em Direito pela Faculdade de Itauna - MG. Mestra em Administração pela UFMG. Doutora em Economia Rural pela UFV. Professora Associada da Universidade Federal de Viçosa - MG.

${ }^{4}$ Bacharel em Direito pela Faculdade de Itaúna - MG. Bacharel em Administração pelo Centro Unversitário UNA - MG. Mestre em Administração pelo FEAD-MG. Professor da Universidade Presidente Antônio Carlos Campus Ponte Nova - MG.
} 


\section{INTRODUÇÃO}

No Brasil, com a liberação do preço dos combustíveis, houve um aumento na concorrência entre as distribuidoras de combustíveis e os varejistas que vendem o produto para o consumidor final - os postos de combustíveis. Esse fato fez com que empresários inescrupulosos passassem a adulterar combustíveis para poder revendê-los a preços mais baixos para os consumidores e ao mesmo tempo aumentar a sua margem de lucro. Concomitantemente, a partir da liberalização do preço por parte do governo, o preço passou a ser mais um dos fatores que influenciam na escolha do varejista por parte do consumidor.

Atualmente, os postos de combustíveis vêm segmentando as suas atividades, com o intuito de conseguir novas fontes de receitas e ao mesmo tempo, sinergia entre possíveis novos negócios e fidelização de clientes com a oferta complementar de produtos e serviços (FERNANDES, 2001). Outro ponto a ser ressaltado, é que a oferta e tanto a sua qualidade como a sua quantidade, são considerados pelos consumidores e, seu processo de avaliação acerca da qualidade geral de um posto de combustível (LIMA, 2008). Para alcançar esses objetivos, os seus gestores terão de decidir e executar estratégias adequadas com o intuito de se alcançar as vantagens competitivas (SANTOS, 2007).

De acordo com o SINDICOM (2009), a gasolina é o produto mais fraudado, pois, apresenta maior consumo e possibilidades para realizar as fraudes. Estas em geral, são realizadas misturando uma maior quantidade de álcool do que o permitido na gasolina (o álcool é mais barato do que a gasolina) e adicionando-se outros produtos, como por exemplo, solventes de tintas.

Os malefícios causados pela utilização de combustível adulterado são muitos. Tem-se o impacto ambiental e econômico para o governo e cidadãos. O produto adulterado pode causar muitos danos como um todo, desde ao frentista do posto de gasolina que manipula o produto, até mesmo à sociedade de uma maneira em geral, pois produz mais resíduos e consequentemente mais poluição, sendo que alguns destes resíduos são cancerígenos.

Os automóveis após serem fabricados são disponibilizados ao mercado apresentando uma configuração do motor (componentes mecânicos e eletrônicos) programada para funcionar de acordo com as regulamentações técnicas da ANP (Agência Nacional de Petróleo). Portanto, a utilização de combustíveis com características químicas diferentes dos padrões da ANP, pode causar diversos danos ao motor dos automóveis. De acordo com o SINDICOM (2009), entre os efeitos danosos que a gasolina adulterada pode causar aos motores, pode-se citar: falhas no funcionamento adequado do motor; dificuldade na inicialização do motor; maior emissão de gases e poluentes, com aumento também do 
consumo; a marcha lenta fica instável; perda de potência do motor e conseqüente queda no desempenho do automóvel.

De outro lado, a ANP já contatou diversas instituições para monitorar a qualidade dos combustíveis em 18 estados além do Distrito Federal, o que equivale a mais de $90 \%$ do total de postos revendedores de combustíveis. Assim, diversas instituições foram contratadas para coletar as amostras e analisá-las, com o intuito de verificar se as mesmas estão em conformidade com os critérios adotados pela ANP. Em Minas Gerais, o CETEC (Fundação Centro Tecnológico de Minas Gerais) e a UFMG (Universidade Federal de Minas Gerais) são os responsáveis pela fiscalização de mais de 3.500 postos de combustíveis e pela coleta e análise de mais de 17.000 amostras por ano. No Brasil, serão vistoriados aproximadamente 26.500 postos e coletadas e analisadas, 133.500 amostras de combustível (ANP, 2002).

\section{JUSTIFICATIVA}

A importância e os benefícios advindos dos estudos do comportamento do consumidor são notórios. Dentre eles, podem-se destacar o fortalecimento da própria teoria do comportamento do consumidor, passando pela melhor compreensão da teoria do marketing e influenciando questões governamentais e de políticas públicas. A compreensão do processo de compra do consumidor é de primordial importância para as empresas, pois a partir deste processo - que pode ser cognitivo ou impulsivo/condicionado dependendo do produto - é que o consumidor não só decide pela compra ou não do produto, como também decide quando e como comprar, além de decidir o quanto gastar. Também é possível compreender melhor como as possíveis consequiências dos seus atos, bem como o processo de agir que influencia o seu processo decisório. Assim, é possível coletar uma série de informações importantes que facilitarão a compreensão do processo de escolha por parte dos indivíduos em relação à compra de gasolina. Além disso, atualmente os consumidores estão no centro das atenções das empresas. A própria definição de marketing enfatiza o processo de trocas entre as pessoas (MOWEN; MINOR, 2003).

Outro ponto a ser considerado é que existem poucos estudos em nível de doutorado e mestrado sobre o comportamento do consumidor de gasolina. Por meio de uma pesquisa ao banco de teses da CAPES (Coordenação de Aperfeiçoamento de Pessoal de Nível Superior) foi possível observar que os estudos mercadológicos e notadamente relacionados ao comportamento do consumidor não chegam a cinco em todo o Brasil há mais de 10 anos (considerando o período do ano 2000 a 2010). Outra pesquisa realizada foi utilizando os anais do ENANPAD ( Encontro Nacional da Associação Nacional de Pós - Graduação em 
Administração), no qual somente um trabalho que analisa a lealdade em relação aos postos de combustíveis foi encontrado. Os resultados indicam que esse tema ainda é pouco explorado, pelo menos no contexto brasileiro.

Alguns desses estudos pesquisaram os atributos mais importantes para os consumidores em postos de combustível (PATRÍCIO, 2003), as relações entre qualidade, satisfação e reputação de marca (SANTOS, 2007), principais atributos utilizados pelos gestores de postos de combustível para aumentar a sua competitividade (FERNANDES, 2001), e a relações da cadeia meio-fim entre os atributos e os benefícios que os consumidores percebem em relação à gasolina (LIMA, 2008)

Por outro lado, a ANP já contatou diversas instituições para monitorar a qualidade dos combustíveis em 18 estados além do Distrito Federal, o que equivale a mais de $90 \%$ do total de postos revendedores de combustíveis. Assim, diversas instituições foram contratadas para coletar as amostras e analisá-las, com o intuito de verificar se as mesmas estão em conformidade com os critérios adotados pela ANP No Brasil, serão vistoriados aproximadamente 20.400 postos, e coletadas e analisadas 108.000 amostras de combustível (ANP, 2009). Em março de 2009, o índice de não-conformidade das amostras foi de $2 \%$.

\section{OBJETIVOS}

O objetivo geral - por meio desse estudo - é o de conhecer o comportamento de compra dos consumidores de gasolina. Além disso, têm-se como objetivos específicos:

- Identificar quais são os principais fatores que influenciam e quais os atributos mais importantes na decisão dos consumidores sobre a escolha de um posto de gasolina.

- Verificar se os consumidores testam se a gasolina que compram é de boa qualidade.

- Verificar se os consumidores conhecem os efeitos do uso de gasolina adulterada.

- Verificar se existem diferenças significativas entre homens e mulheres em relação aos atributos mais importantes dos postos de combustíveis, comportamento de compra, percepção de risco e o trabalho feminino nos postos de combustíveis.

Assim, este trabalho procura responder as seguintes perguntas: como é o comportamento do consumidor de gasolina? O que ele considera mais importante em um posto de combustível ao adquirir gasolina? A partir desse conhecimento, quais as estratégias mercadológicas mais adequadas podem ser elaboradas pelos participantes desse setor?

\section{REVISÃO TEÓRICA}

O Comportamento do Consumidor pode ser definido como "atividades com que as 
pessoas se ocupam quando obtêm, consomem e dispõem de produtos e serviços" (ENGEL; BLACKWELL; MINIARD, 2005, p. 6). Nesse caso, o entendimento de produto deve ser o mais amplo possível, onde se inclui qualquer coisa que possa ser utilizada para satisfazer o desejo do consumidor. Assim, serviços, idéias, lugares ou pessoas também podem ser considerados como produtos (KOTLER; KELLER, 2006).

De acordo com o conceito de Engel; Blackwell e Miniard (2005), comportamento do consumidor diz respeito a atividades e processos anteriores e posteriores à compra ou ao consumo de forma geral. As atividades de busca de informações acerca do produto ou o crescente desejo pela posse do mesmo, e ainda, o processo de avaliação das marcas e modelos existentes são exemplos de atividades ou fases pré-compra. Por outro lado, as avaliações realizadas pelos consumidores acerca do produto comprado, reclamações em caso de insatisfação e descarte de produtos que perderam sua funcionalidade são exemplos de processos posteriores à compra. No caso de bens de especialidade ou produtos com maior conteúdo tecnológico que exigem muitas informações para a decisão de compra, o processo decisório pode ser bastante complexo, gerando insegurança e desconforto psicológico no consumidor (PACHAURI, 2002).

De acordo com Simonson et al. (2001) apesar dos grandes avanços alcançados nas pesquisas sobre o comportamento do consumidor, ainda existem muitas discordâncias acerca do seu conceito, dos seus objetivos e das suas relações com outras disciplinas. Segundo Mowen e Minor (2003), três perspectivas funcionam como diretrizes para o pensamento do comportamento do consumidor e para identificar as variáveis que o influenciam:

- Tomada de decisão: interpretação do ciclo de consumo como a resolução racional de um problema. É apresentada como a sucessão lógica de etapas: reconhecimento de um problema, busca de alternativas, avaliação de opções, escolha e a avaliação póscompra.

- Experimental: perspectiva que inclui na análise elementos emocionais e subjetivos, pois o consumo também é buscado para satisfazer desejos, fantasias e vivenciar emoções. Por exemplo, a compra por impulso e a busca por variedade.

- Influência comportamental: reconhecimento de que muitas decisões de consumo são desencadeadas por forças ambientais que levam o consumidor à ação, independentemente de serem ou não antecipadas pela elaboração de crenças e sentimentos acerca do produto. O consumidor não passa necessariamente por um processo racional ou então desenvolve sentimentos pelo produto.

Em seu estágio inicial, a pesquisa do comportamento do consumidor considerava apenas os princípios teóricos emprestados da Economia para explicar as preferências do consumidor 
em virtude da oferta, renda e preços. Somente a partir da década de 50, as pesquisas sobre o comportamento do consumidor começaram a ser tratadas como um assunto referente aos estudos de marketing (LAWSON, 2000). De acordo com Pachauri (2002), o comportamento do consumidor atingiu status de campo de estudo na década de 60. O principal impulso nessa época foi a criação da Associação de Pesquisa do Consumidor em 1969, e logo após, foi criada o periódico "Journal of Consumer Research" (1974).

As crenças podem ser conceituadas como a percepção de um indivíduo que acredita que um determinando objeto ou pessoa possui certos atributos, qualidades e características (FISHBEIN; AJZEN, 1972). Para Bennett e Kassarjian (1975):

[...] uma crença (ou opinião) é uma cognição emocionalmente neutra ou um 'conhecimento' de um indivíduo sobre algum aspecto de um objeto do ambiente isto é, as coisas que a pessoa 'sabe' que são verdadeiras, a partir de seu próprio ponto de vista, consistindo dos fatos sobre alguma coisa, como a pessoa os vê, num determinado momento (BENNET; KASSARJIAN, 1975, p.101).

As relações entre crenças, atitudes, intenções e comportamento podem ser entendidas da seguinte forma. O indivíduo, por meio da sua percepção do mundo, aprende sobre os objetos - pessoas, lugares, coisas, animais e etc. Esse aprendizado leva as pessoas a formarem crenças, as quais influenciam as atitudes das pessoas em relação ao mundo, aos objetos e afins. As atitudes estão relacionadas diretamente com as crenças de uma pessoa. Diversas relações significativas entre atitudes e crenças já foram e ainda são descritas pelos estudiosos (FISHBEIN; AJZEN, 1972). De acordo com Mowen e Minor (2003), a origem das crenças está relacionada com a aprendizagem cognitiva e processamento de informações, pois estão associadas ao conhecimento que as pessoas têm a respeito dos objetos (coisas do mundo real das quais os indivíduos possuem opiniões), suas características - atributos, qualidade, aspectos - e os benefícios (resultados) advindos deles. Nem sempre as crenças serão verdadeiras. Outro ponto a ser considerado na formação das crenças é que as pessoas - em geral - dão mais importância às informações negativas do que as positivas no processo de aprendizado de sobre um determinado objeto, o que pode servir como um processo de viés da realidade (AJZEN, 2001). 


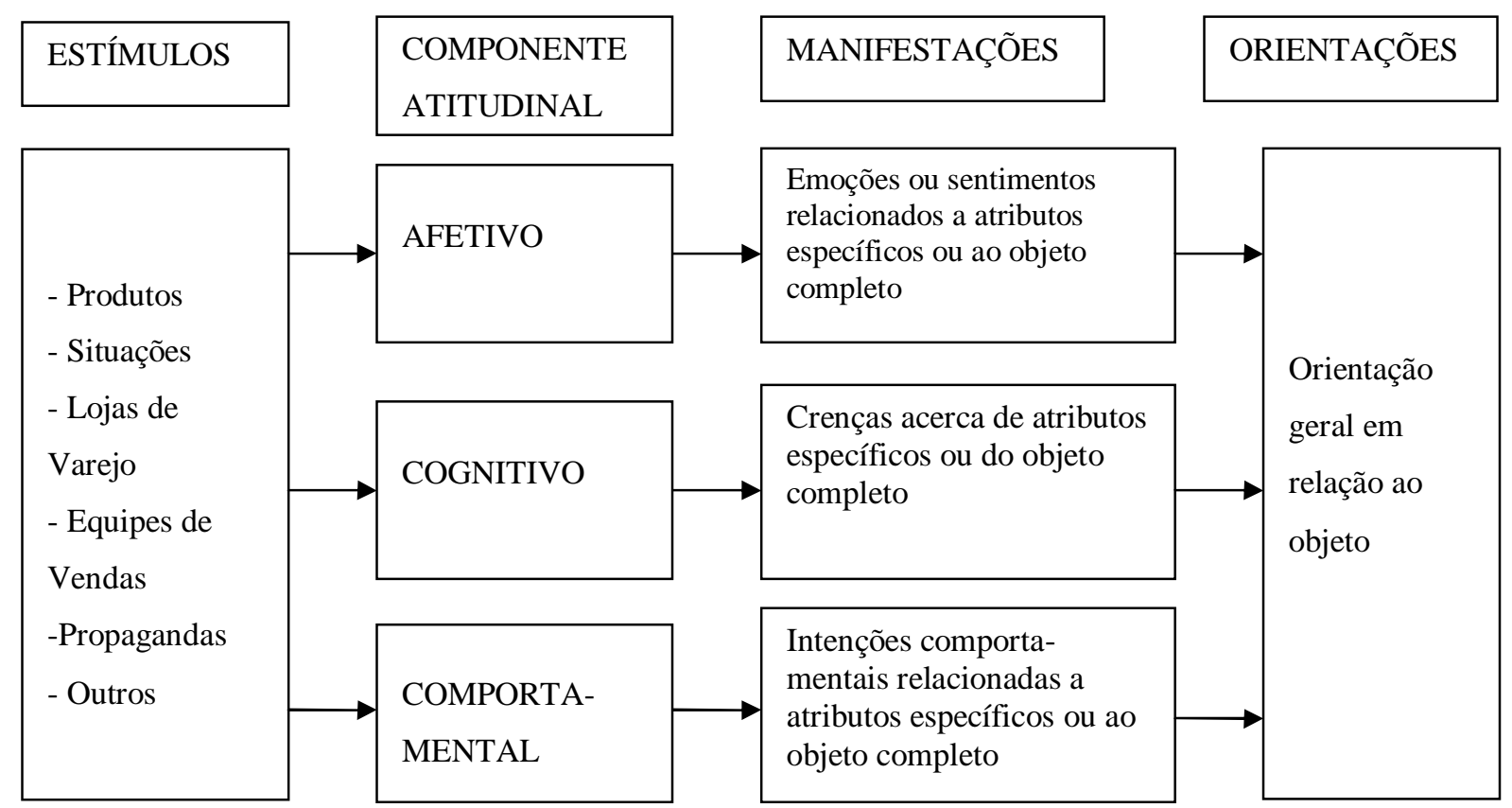

Figura 1. Componentes e manifestações da atitude.

Fonte: adaptado de Hawkins, Mothersbaugh e Best (2007, p. 201).

As atitudes podem ser entendidas como um composto formado por itens cognitivos (oriundos das crenças dos indivíduos), itens afetivos (formados pelas emoções e sentimentos das pessoas) e itens comportamentais (gerados a partir das intenções comportamentais dos sujeitos). As atitudes caracterizam-se basicamente pela predisposição das pessoas a responderem de forma favorável ou desfavorável a respeito de um objeto (FISHBEIN; AJZEN, 1972). É uma predisposição em comportar-se de determinada forma em relação a um determinado objeto, seja de forma favorável ou não, por meio da organização de processos cognitivos, emocionais e motivacionais (HAWKINS; MOTHERSBAUGH; BEST, 2007).

Como as atitudes são formadas a partir das crenças facilmente acessíveis pelos indivíduos, quaisquer mudanças nessas últimas deverão - em princípio - gerar mudanças nas primeiras. São essas crenças que prevalecem na formação das atitudes das pessoas (AJZEN; FISHBEIN, 2000).

Os consumidores procedem de diferentes maneiras durante o processo de compra em relação a diferentes produtos e marcas (CANTON; GRISI; SANTOS, 1989). O processo de escolha e modo de agir dos consumidores também sofrem influência de fatores culturais, sociais, pessoais, psicológicos, econômicos etc. (KOTLER; KELLER, 2006). De acordo com Canton, Grisi e Santos (1989) e Karsaklian (2000), o envolvimento dos consumidores com o processo de compra dos produtos depende de fatores que podem influenciá-lo isoladamente ou em conjunto: preço, ocasião de uso, percepção de riscos, interesse, visibilidade social e valor simbólico do produto. Esse envolvimento afeta diretamente o comportamento dos consumidores. Um consumidor altamente envolvido procura muitas informações e as analisa 
com mais cuidado (KARSAKLIAN, 2000). Em relação aos riscos, Canton, Grisi e Santos (1989) salientam que a percepção do risco e o envolvimento no processo de compra são diretamente proporcionais, isto é, quanto maior a percepção de risco, maior será o envolvimento do consumidor e vice-versa. Isto ocorre em função das possíveis consequiências negativas advindas de uma compra mal feita, mesmo que o produto tenha um preço baixo. Muitas vezes, os consumidores compram produtos mais caros com o objetivo de reduzir a sensação de risco (SHAPIRO, 1986).

Um aspecto peculiar em relação à gasolina se atém ao fato de que muitos consumidores adquirem esse produto, mas o contato por meio dos cinco sentidos com esse produto é muito pequeno, ou seja, o contato é indireto (LIMA, 2008).

Além disso, Canton, Grisi e Santos (1989) explicam que a ocasião de uso do produto, também influência na percepção dos riscos por parte dos consumidores. Assim, produtos que são comprados e consumidos rotineiramente, possuem uma percepção de risco baixa, ao contrário daqueles comprados de "tempos em tempos". Outro ponto a ser considerado é a visibilidade do produto. Aqueles que podem ser notados por grupos de pessoas (amigos, família, colegas de trabalho e afins) possuem uma percepção de risco maior, do que aqueles como a gasolina - que não podem ser vistos.

Santos (2007) e Lima (2008), identificaram que a compra de combustível é uma ação habitual, onde o consumidor primeiro utiliza o produto e depois o avalia. Além disso, em função da rotina, muitas marcas passam a ser consideradas de qualidade a partir do hábito do seu uso. Outro ponto identificado é que a percepção entre qualidade do produto possui uma correlação positiva com o preço percebido, ou seja, existe uma relação entre preço e qualidade. Por outro lado, aqueles que consideram o preço um item fundamental para a escolha de um posto de combustível, principalmente aqueles mais baratos, consideram que o risco vale a pena em função da economia gerada.

Em relação à importância do público feminino, Peters (1998) explica que cerca de 50\% das viagens de negócios eram realizadas por mulheres. Em 1970 esse percentual era de 1\%. Por isso, diversos hotéis procuram agregar mais valor para o público feminino, investindo em detalhes que são valorizados pelo mesmo. Por exemplo, inclusão de espelhos de corpo inteiro nos quartos. Além disso, a inserção da mulher no mercado de trabalho ocasionou profundas modificações no mercado consumidor. Os homens compram produtos para o lar e as mulheres adquirem produtos - antes praticamente restrito ao universo masculino - como serviços financeiros, viagens e automóveis (BARTOS, 1998). Isto significa que os papéis exercidos pelo homem de cuidar das coisas de fora de casa - seguros, viagens, financiamentos, etc. - e da mulher de cuidar das coisas domésticas - limpeza, decoração, supermercado, etc. - estão 
mudando à medida em que a mulher assume o mercado de trabalho (SCHEWE; SMITH, 1982).

A família desempenha um papel importante no processo de compra das pessoas. No caso das mulheres, elas influenciam de forma significativa a maioria das decisões de compra. No caso de moradia, 95\% das decisões são das mulheres. Em relação aos automóveis, elas influenciam significativamente cerca de $80 \%$ de todas as vendas (PETERS, 1998). No Brasil, são responsáveis pela aquisição de $33 \%$ dos carros com motores de 1.4 a 1.6 (carros pequenos), $30 \%$ dos carros médios, $25 \%$ das caminhonetes e $23 \%$ dos carros considerados grandes (MICHELAZZO, 1998). No caso da FIAT, as mulheres são responsáveis por 40\% das vendas da empresa e $45 \%$ das compras do Ford KA é realizada por mulheres. Diante desse quadro, as empresas automobilísticas brasileiras estão investindo cada vez mais em produtos que agradem as mulheres. Por exemplo, os bancos possuem um revestimento mais macio para não estragar as meias, o desenho das maçanetas foi alterado para não quebrar as unhas, inclusão de espelho no pára-sol do motorista e assim por diante (MAIA, 2001).

\section{METODOLOGIA}

Essa é uma pesquisa descritiva e, segundo Malhotra (2001), é um tipo de pesquisa conclusiva cujo maior objetivo é a descrição de algo, geralmente características de mercado ou funções. A pesquisa teve duas etapas. A primeira etapa, qualitativa, consiste na consulta de bibliografia sobre o assunto, análise de pesquisas qualitativas com os consumidores de gasolina e profissionais do setor de postos de combustíveis. A segunda etapa corresponde à pesquisa quantitativa, descritiva (survey) feita junto aos consumidores de gasolina.

Com o objetivo de melhor conhecer as opiniões, os critérios de escolha, a percepção de risco ao comprar gasolina e afins, foram realizados dois grupos de foco com consumidores que abastecem os seus automóveis com gasolina. A partir dos dados obtidos nesta pesquisa, foi possível elaborar o instrumento de coleta de dados - questionário - adequado para que se atinja os objetivos desta pesquisa, além de proporcionar uma melhor visão e compreensão à respeito do contexto do problema. Em relação ao grupo de foco, Malhotra (2001), afirma que esta é uma entrevista realizada com um pequeno grupo de respondentes - de 8 a 12 pessoas que fazem parte do público-alvo da pesquisa. Um moderador treinado conduz a entrevista para que os participantes possam expor as suas opiniões e para que o assunto da discussão se mantenha dentro do escopo previamente desejado pelos pesquisadores. Depois, o moderador ajudará na interpretação dos grupos de foco, a partir da sua participação nos mesmos e registro das discussões em algum meio audiovisual. O número de sessões de grupos de foco 
varia, mas depende em geral da quantidade de novas informações apresentadas, custo, tempo e tipo de problema a ser pesquisado.

Além dos dois grupos de foco, também foram realizadas seis entrevistas com gerentes e proprietários de postos de combustíveis, com o objetivo de conhecer melhor o problema e a opinião dos mesmos em relação ao comportamento de compra dos seus clientes. Em relação às entrevistas, Marconi e Lakatos (1986) explicam que elas ocorrem com o encontro de duas pessoas, portanto é uma conversação realizada face-a-face, em que uma destas obtém as informações que deseja da outra pessoa, através de uma conversa de natureza profissional e de forma metódica. A entrevista tem algumas vantagens sobre outras técnicas, devido ao fato de que pode ser utilizada com pessoas de todos os segmentos sociais. O entrevistador pode esclarecer e tirar dúvidas do entrevistado acerca das perguntas propostas, pode-se observar gestos, atitudes e reações do entrevistado.

Ainda, de acordo com esses autores, a entrevista focalizada é realizada através de uma lista de tópicos que devem ser abrangidos, mas o entrevistador determina a ordem e a maneira de propor as perguntas.

Neste trabalho também foi utilizado o contato pessoal tendo como instrumento de coleta de dados o questionário. Segundo texto de Marconi e Lakatos (1986) a elaboração de um questionário requer a observância de normas precisas, a fim de aumentar sua eficácia e validade. Em sua organização se deve levar em conta os tipos, a ordem, os grupos de perguntas, a formulação das mesmas e também tudo que se sabe sobre percepção, estereótipos, mecanismos de defesa, liderança e etc. Após a elaboração do instrumento de coleta dos dados, foi realizado o pré-teste - do questionário junto aos consumidores de gasolina. Os resultados além de servirem de embasamento para alterações e melhorias no questionário original, também foram utilizados para o cálculo do tamanho representativo da amostra. Assim, foram aplicados 35 questionários, com o intuito de se identificar os problemas e pontos duvidosos que os mesmos apresentavam para os respondentes. Além das questões relacionadas a aspectos demográficos e comportamentais que apresentam escalas nominais, o questionário apresentou dois blocos de perguntas. O primeiro relacionava-se às crenças dos consumidores acerca dos riscos, comportamento e participação feminina nas atividades dentro de um posto de combustível, formado por 16 questões com escalas intervalares de nove pontos unipolares do tipo Likert com as âncoras "concordo/discordo plenamente". No segundo bloco, é mensurado o nível de importância de acordo de sete itens com escalas intervalares de nove pontos unipolares do tipo Likert com as âncoras "baixa/alta importância".

Foram seguidas as técnicas recomendadas por Malhotra (2001) que descreve que o 
propósito do pré-teste é o de melhorar o questionário pela identificação e eliminação de problemas em potencial. O pré-teste deve ser realizado com o mesmo público-alvo da pesquisa, ou seja, a amostra do pré-teste deve possuir as mesmas características da amostra a ser pesquisada.

A aplicação dos questionários, bem como as entrevistas, ocorreu em uma metrópole brasileira. As unidades de observação são os compradores de gasolina e profissionais que atuam no setor. As unidades de análise são os consumidores de gasolina que residem na cidade onde ocorreu o estudo. Contudo, apesar da unidade de análise se referir aos consumidores de uma metrópole, a amostragem utilizada não foi probabilística, pois, a mesma não garante a completa aleatoriedade dos dados obtidos. O público-alvo desta pesquisa são consumidores de gasolina, ou seja, aquelas pessoas que efetivamente compram o produto em postos de gasolina. Estes clientes deverão abastecer automóveis. Não fazem parte do públicoalvo, aquelas pessoas que utilizam o automóvel, mas não compram gasolina. Também não fazem parte aqueles que abastecem motocicletas - pois os efeitos da adulteração de combustíveis são bem menores do que no caso dos automóveis -, caminhões - que utilizam óleo diesel - e ônibus. A realização da pesquisa ocorreu em cinco postos de gasolina localizados em locais distintos nessa metrópole, sendo que a sua escolha deveu-se à conveniência e aquiescência dos responsáveis pelos postos de gasolina. Assim, essa amostra é classificada como por conveniência, a qual segundo Malhotra (2001) é uma amostragem não probabilística, em que a seleção das unidades amostrais é baseada na obtenção de elementos convenientes, ou seja, eles estão no lugar adequado no momento oportuno. É a mais rápida e mais barata, pois os elementos são fáceis e rápidos de serem encontrados.

A participação destes postos consistiu na concessão de autorização ao pesquisador para abordagem de clientes em suas instalações. O público foi abordado enquanto aguardava na fila para lavagem de seus veículos - filas de ducha automotiva. Em alguns casos, os clientes que esperavam por troca de óleo também foram abordados. A escolha pelas filas das duchas se deu pela conveniência operacional, uma vez que clientes dos postos interessados apenas em abastecer quase sempre querem a maior rapidez possível - incompatível com os minutos requeridos para preenchimento do questionário - e pela imposição dos proprietários e gerentes dos postos, que não permitem qualquer tipo de atividade que possa prejudicar o fluxo de clientes nas bombas de combustível.

Para o cálculo do tamanho da amostra considerou-se a fórmula de determinação do tamanho pela média, extraída de Malhotra (2001, p. 394) : 


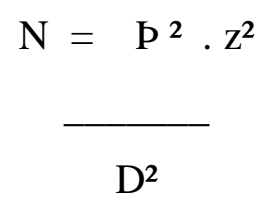

Onde n é o tamanho da amostra.

D representa o nível de precisão.

$Z$ representa o intervalo de confiança.

P representa o desvio padrão.

Nesse estudo, o nível de precisão foi de 0,35 pontos, sendo que o intervalo de confiança é de $95 \%$ e o valor de $Z=1,96$ (teste $Z$ ). O maior desvio padrão encontrado foi de 2,98 utilizando-se uma escala de um a nove pontos. Por conseguinte, o tamanho calculado da amostra foi de 278 questionários, sendo que se obteve 290 questionários válidos do total de 326 questionários aplicados. O alto número de questionários considerados inválidos deveu-se à grande quantidade de respostas em branco e de questionários respondidos de forma parcial. Isso foi consequência do fato de que quando o serviço do posto de combustível terminava, os respondentes - muitas vezes - iam embora, deixando muitas respostas em branco.

Apesar da amostra não ser probabilística e, portanto, não permitir generalizações, o seu cálculo é útil para identificar o nível de precisão dos resultados a serem obtidos.

A variância considerada foi resultante da análise das perguntas que formam o questionário submetido ao pré-teste. Em seguida calcula-se o desvio padrão referente a essas perguntas - escolhendo-se a maior variância encontrada entre as mesmas, ou seja, escolhendose a pergunta que apresenta a menor homogeneidade (maior heterogeneidade) de acordo com o público-alvo da pesquisa.

\section{ANÁLISE DE DADOS}

\section{ANÁLISE QUALITATIVA}

Os resultados dos dois grupos de foco e das entrevistas realizadas apontam uma série de aspectos, sendo que parte dos mesmos foi mensurada por meio da aplicação dos questionários.

Em relação aos grupos de foco, pode-se observar que houve uma unanimidade em relação à importância do atendimento do posto de combustível pelos consumidores de gasolina. Nesse caso, o atendimento é um fator fundamental em virtude de que o produto em princípio - é o mesmo (gasolina) e a diferença de preços e localização entre postos próximos podem ser muito pequena. Por conseguinte, o atendimento é o grande fator de diferencial e que realmente agrega valor de acordo com a opinião dos participantes dos grupos de foco. Também, foi relatado pelos respondentes que é possível perceber a padronização do atendimento provavelmente em função de treinamentos prévios. 
Outro ponto destacado foram as lojas de conveniência, principalmente pelo público mais jovem. Essas lojas são muitos úteis principalmente nos finais de semana, onde além de abastecer os automóveis, os indivíduos podem lanchar, comprar cerveja, petiscos, tira-gostos, camisinhas, pilhas e uma série de outros produtos. Além disso, alguns postos oferecem um sistema de segurança adequado, além da facilidade de pagamentos usando vários tipos de cartões, o que dispensa os clientes de carregarem dinheiro em espécie.

A aparência dos postos de combustíveis também é considerada importante pelos clientes. Inclusive influencia na percepção da qualidade da gasolina. Os respondentes relataram que postos pequenos e "machucados" (aparentam que precisam de uma grande reforma) não inspiram confiança e quando podem, escolhem outro posto.

Foi descrito que as compras de gasolina em geral não são planejadas. Como sempre abastecem em estabelecimentos que estão no caminho que fazem diariamente, quando o nível da gasolina abaixa, é só "entrar e abastecer". Por outro lado, os profissionais do setor afirmam que a demanda pelo produto é "sazonal" dentro do próprio mês, tendo um grande aumento na época do recebimento do salário dos clientes. Um grupo de clientes também planeja a compra em dias e horários fora do "pico de vendas" - geralmente ao final do dia e cair da noite - com o intuito de serem melhor atendidos e não perderem tempo.

Além disso, em relação à adulteração de combustíveis e suas possíveis consequiências, os participantes dos grupos de foco, em sua maioria, acreditam que os consumidores têm pouco conhecimento a respeito dos problemas que podem ser causados pelo produto adulterado. É algo que as pessoas “ouviram falar", mas não se preocuparam em pesquisar sobre o assunto.

Um dos pontos mais interessantes debatido pelos grupos de foco foi a questão do assédio. O público feminino declarou que uma das coisas que mais as irritam ao abastecer o automóvel são as cantadas e brincadeiras dos frentistas que trabalham nos postos. Um chaveiro com nome ou as iniciais, adesivos colados nos vidros, entre outras coisas servem para que elas sejam alvo de alguma "gracinha". Obviamente com o sistema que destrava a fechadura do tanque de combustível de dentro do carro amenizou esse problema, mas os problemas ainda ocorrem. A sugestão e questionamento foi o porquê do motivo para que mulheres também exerçam essas atividades dentro dos postos de combustíveis. Por outro lado, surgiram dúvidas em relação ao conhecimento, força e até mesmo a questão da segurança para os clientes, caso mulheres trabalhem como frentistas. Essas observações foram consideradas na elaboração do questionário.

Além disso, foi relatado pelos participantes que eles evitam ao máximo abastecer o carro nas estradas. Caso o combustível seja suficiente para chegar ao destino, eles preferem 
abastecer em postos de gasolina localizados dentro da área urbana da cidade de destino. Os respondentes acreditam que nas rodovias exista muito menos fiscalização do que nas cidades, o que colabora para que se tenha uma maior porcentagem de combustível adulterado.

Os participantes dos grupos de foco abastecem geralmente no mesmo posto ou em dois postos. Sempre visando a experiência anterior de que o carro não apresentou problemas e de que a localização ajuda da comodidade dessa compra. Os profissionais do setor de combustíveis também corroboram com esse pensamento. Para eles, cerca de $40 \%$ dos clientes sempre abastecem somente em um posto de combustível.

Em relação à percepção de qualidade, os profissionais do setor acreditam que a bandeira é um fator muito importante para o consumidor, principalmente quando ele não conhece o posto ou o preço cobrado está abaixo do mercado e nesse caso, o posto está trabalhando com margens ainda menores. Por isso, eles apóiam e acham muito importantes as campanhas institucionais das marcas, porque isso se traduz em mais vendas. Inclusive foi declarado que a bandeira, ou seja, a marca do posto, é uma promessa e garantia para os consumidores. Além disso, a aparência do posto e dos frentistas, também ajudam a aumentar a sensação de confiança dos consumidores e as promoções, sorteios e brindes podem ressaltar a imagem da marca e ajudar a criar um hábito de consumo em determinado estabelecimento.

De acordo com Patrício (2003) a marca de uma distribuidora de combustíveis é a sua bandeira. $\mathrm{O}$ posto ele pode estar ou não vinculado a uma distribuidora por meio de contratos de exclusividade ou não. De toda forma, em cada bomba de combustível, deve constar a distribuidora fornecedora do produto.

A importância da localização também foi ressaltada. Ao contrário de outros tipos de comércio que somente podem existir em locais com grande movimento de pessoas ou no centro da cidade, existem muitos postos de combustíveis "de bairro". Essa localização permite que os consumidores abasteçam seus veículos sem sair do seu caminho habitual, gerando comodidade para os mesmos.

Os profissionais dos postos acreditam que a influência familiar existe, mas não é igual para as pessoas, principalmente considerando-se o gênero. Assim, as mulheres seriam mais influenciadas pelos homens, sejam eles maridos, irmãos, pais ou namorados. Os homens por outro lado, não sofrem tanto essa influência, principalmente se ela vem de uma mulher.

Por fim, apesar de ser um direito do consumidor e de que grande parte dos mesmos terem ciência disso, de acordo com os donos e gerentes de postos de combustíveis, a solicitação da realização de testes de combustível por parte dos clientes é muito pequena. 


\section{TRATAMENTO DOS DADOS E CARACTERÍSTICAS DA AMOSTRA}

O objetivo é identificar se as questões não-respondidas ou respondidas parcialmente pelos entrevistados podem comprometer as análises a serem realizadas, bem como descobrir possíveis tendências no não preenchimento destas questões. Esse fato pode causar viéses nas inferências encontradas na amostra estudada, bem como pode acarretar uma diminuição na confiabilidade das análises estatísticas conduzidas em decorrência da redução do tamanho da amostra. A aleatoriedade da ausência de dados de uma amostra é um pressuposto importante. Isto significa que não existe uma diferença sistemática entre os dados coletados e os dados ausentes, ou seja, ambos são um subconjunto aleatório dos elementos que compõem todo o universo de pesquisa (NEWTON; RUDESTAM, 1999).

Assim, foi realizada uma análise descritiva dos dados faltantes para cada variável. Nenhuma questão apresentou um índice superior a 5\% de dados faltantes - em números absolutos, 14,5 respostas de um total de 290 questionários. A questão que apresentou maior número de não-respostas teve cinco registros em branco.

Caso alguma variável tivesse apresentado mais do que 5\% de dados ausentes, seria realizado um teste $\mathrm{t}$ entre os questionários nos quais a variável está ausente e presente para verificar se existe alguma diferença estatisticamente significativa. Contudo, de acordo com Tabachnick e Fidell (2001), somente as variáveis com mais de 5\% de dados faltantes devem ser consideradas na análise do teste $t$ de aleatoriedade.

Além disso, foi realizado o Teste Little's MCAR. Para Hair et al. (1998) este teste permite verificar se o comportamento dos dados ausentes é completamente ao acaso (AACA nível mais alto de aleatoriedade de dados), ou seja, se realmente os valores observados para uma variável qualquer representam uma amostra aleatória para todos os valores existentes desta variável. Assim, este teste analisa os padrões de ausência de dados de todas as variáveis e os compara com os valores esperados em relação ao processo aleatório de dados ausentes. Como o resultado obtido foi de 0.000 (significante) não é possível considerar os dados ausentes completamente ao acaso e utilizar métodos de correção e imputação de dados.

Outro pressuposto que deve ser verificado é o padrão de distribuição das variáveis estudadas. Para tal, foi realizado o teste de normalidade de Kolmogorov-Smirnov para os itens das questões acerca da importância dos atributos do posto de gasolina, da gasolina e itens relacionados ao comportamento dos consumidores (23 itens no total). Todas elas apresentaram valores significativos 0.000 , ou seja, nenhuma dessas variáveis possui uma distribuição normal.

Em relação às características da amostra, a grande maioria dos entrevistados é do sexo masculino $(75,1 \%)$ do total, sendo que os grupos dos casados/união estável e solteiros são 
muito parecidos com $47,6 \%$ e $44,1 \%$ do total de respondentes, respectivamente. Verificandose a faixa etária, o maior grupo é aquele formado pelos indivíduos entre 18 e 25 (24,1\% do total), seguido pelos grupos de 34 a 41 anos e 42 a 49 anos, com 19,7\% do total cada um. A escolaridade predominante é a dos que cursaram um terceiro grau - 47,3\% do total. A renda é muito variável, sendo que aqueles que recebem mais de 4.200 reais por mês formam o maior grupo, seguido daqueles que ganham entre 841 e 1.680 reais, com $28,1 \%$ e $18,1 \%$ do total respectivamente.

\section{ANÁLISE DESCRITIVA}

O próximo passo da análise de dados foi analisar de forma descritiva as questões relacionadas às afirmativas sobre as crenças, percepção de risco, compra de gasolina e aos atributos mais importantes para o consumidor de gasolina e o seu comportamento de compra.

Tabela 1 - Frequência de abastecimento do automóvel

\begin{tabular}{l|cc}
\multicolumn{1}{c|}{ Frequência de abastecimento } & Percentual & Percentual Acumulado \\
\hline Menos de 1 vez por mês & 1,4 & 1,4 \\
1 vez por mês & 5,9 & 7,3 \\
2 a 3 vezes por mês & 31,4 & 38,6 \\
1 vez por semana & 33,5 & 72,2 \\
2 vezes por semana & 13,0 & 85,1 \\
3 ou mais vezes por semana & 14,9 & 100,0 \\
Total & 100,0 & \\
\hline
\end{tabular}

Quanto à frequência de abastecimento do automóvel: do total de respostas válidas para esta questão (290 entrevistados), verifica-se que a maioria dos entrevistados abastece seu veículo uma vez por semana ou de duas a três vezes por, com 33,5\% e 31,4\% da amostra, respectivamente. Os consumidores entrevistados que abastecem três ou mais vezes por semana totalizaram $14,9 \%$ da amostra, e os que abastecem 2 vezes por semana, $13 \%$. Os consumidores que abastecem apenas uma vez por mês totalizaram 5,9\% da mostra e, com $1,4 \%$ do total, estão os consumidores que abastecem menos de uma vez por mês. 
Tabela 2 - Litros em média por abastecimento do automóvel

\begin{tabular}{l|cc}
\hline \multicolumn{1}{c|}{ Litros por abastecimento } & Percentual & $\begin{array}{c}\text { Percentual } \\
\text { Acumulado }\end{array}$ \\
\hline Até 10 litros & 12,2 & 12,2 \\
Entre 11 e 20 litros & 22,4 & 34,6 \\
Entre 21 e 30 litros & 24,1 & 58,6 \\
Entre 31 e 40 litros & 19,7 & 78,4 \\
Mais de 41 litros & 21,6 & 100,0 \\
Total & 100,0 & \\
\hline
\end{tabular}

Quanto ao número de litros comprados por abastecimento: do total de respostas válidas para esta questão (290 entrevistados), verifica-se que a maioria da amostra adquire de 21 a 30 litros de gasolina por abastecimento, com $24,1 \%$ do total. Em seguida, com $22,4 \%$, estão os consumidores que adquirem de 11 a 20 litros por vez, percentual muito próximo dos 21,6\% que adquirem mais de 41 litros. Os consumidores entrevistados que abastecem de 31 a 40 litros totalizam $19,7 \%$ da amostra e, por final, 12,2\% do total adquirem até dez litros por abastecimento. A tabela 8 apresenta a percepção acerca do comportamento de compra dos clientes.

Tabela 3 - Realização de compras em loja de conveniência durante abastecimento

\begin{tabular}{l|cc}
\hline \multicolumn{1}{c|}{ Compras de conveniência } & Percentual & $\begin{array}{c}\text { Percentual } \\
\text { Acumulado }\end{array}$ \\
\hline Já comprou & 80,0 & 80,0 \\
Nunca comprou & 20,0 & 100,0 \\
Total & 100,0 & \\
\hline
\end{tabular}

Quanto a realização de compras em loja de conveniência durante abastecimento: do total de respostas válidas para esta questão, verifica-se que a grande maioria dos consumidores entrevistados já realizou alguma compra desta natureza, com $80 \%$ do total; os consumidores que nunca realizaram tal compra totalizam $20 \%$ da amostra.

Tabela 4 - Comprovação da qualidade do combustível através de teste durante abastecimento

\begin{tabular}{l|cc}
\multicolumn{1}{c|}{ Comprovação da qualidade } & Percentual & $\begin{array}{c}\text { Percentual } \\
\text { Acumulado }\end{array}$ \\
\hline Já comprovou & 23,2 & 23,2 \\
Não comprovou & 76,8 & 100,0 \\
Total & 100,0 & \\
\hline
\end{tabular}


Quanto a comprovação da qualidade do combustível através de teste durante abastecimento: do total de respostas válidas para esta questão, verifica-se que a grande maioria dos entrevistados nunca realizou esta comprovação, com mais de três quartos da amostra. A parcela referente aos consumidores que já realizaram a comprovação da qualidade do combustível através de teste durante abastecimento corresponde a 23,2\% do total de consumidores entrevistados.

Tabela 5 - Conhecimento do direito do consumidor de exigir o teste da gasolina no ato de abastecer

\begin{tabular}{lccc}
\hline & Conhecimento do direito & Percentual & $\begin{array}{c}\text { Percentual } \\
\text { Acumulado }\end{array}$ \\
\hline Conhecia & 57,0 & 57,0 \\
Não conhecia & 43,0 & 100,0 \\
Total & 100,0 & \\
\hline
\end{tabular}

Quanto ao conhecimento do direito ao teste da gasolina: do total de respostas válidas para esta questão, verifica-se que a maioria dos consumidores entrevistados com $57 \%$ do total, conhece tal direito. Por outro lado, $43 \%$ da amostra desconhece o direito ao teste da gasolina que está sendo abastecida no veículo.

Tabela 6 - Número de postos em que se abastece o automóvel no dia-a-dia

\begin{tabular}{l|cc}
\hline \multicolumn{1}{c|}{ Número de postos } & Percentual & $\begin{array}{c}\text { Percentual } \\
\text { Acumulado }\end{array}$ \\
\hline 1 posto de gasolina & & 25,1 \\
2 postos de gasolina & 46,1 & 71,9 \\
3 postos de gasolina & 19,5 & 91,4 \\
4 ou mais postos de gasolina & 8,6 & 100,0 \\
Total & 100,0 & \\
\hline
\end{tabular}

Quanto ao número de postos utilizados no dia-a-dia: do total de respostas válidas para esta questão verifica-se que a maioria da amostra abastece cotidianamente em dois postos de gasolina. Essa parcela representa $46,8 \%$ do total, seguida por $25,1 \%$ referentes aos consumidores que abastecem em um único posto. Os consumidores entrevistados que abastecem em três postos totalizam 19,5\% da amostra e, por fim, os que abastecem em quatro postos ou mais representam a menor parcela $-8,6 \%$ do total. 
Tabela 7 - Motivos para sempre se abastecer nos mesmos postos

\begin{tabular}{l|cc}
\hline \multicolumn{1}{c|}{ Motivos } & Percentual & $\begin{array}{c}\text { Percentual } \\
\text { Acumulado }\end{array}$ \\
\hline Não responderam & 6,8 & 6,8 \\
Sempre fico em dúvida, mas acabo indo ao mesmo posto & 9,2 & 15,9 \\
Já tenho o hábito de abastecer lá & 41,1 & 57,0 \\
Nem penso muito sobre isto. Já vou lá e pronto & 12,4 & 69,5 \\
Porque eu analiso as opções e acredito que faço boa compra & 30,5 & 100,0 \\
Total & 100,0 & \\
\hline
\end{tabular}

Quanto aos motivos para se abastecer sempre no mesmo posto: do total de respostas válidas para esta questão, verifica-se que $41,1 \%$ da amostra apontou como motivo o hábito já estabelecido de abastecer em determinado(s) posto(s), e 30,5\% do total apontou como motivo o resultado da análise das opções disponíveis. Em seguida, 12,4\% da amostra respondeu que nem pensa muito sobre o assunto - esta parcela se dirige ao posto sem despender muitos esforços para escolha - e 9,2\% do total indicou que apesar de sempre ficar em dúvida, acaba se dirigindo ao mesmo posto. Não respondeu esta questão 6,8\% do total de consumidores entrevistados - vale ressaltar que esta questão deveria ser respondida apenas por aqueles que têm o hábito de abastecer sempre no(s) mesmo(s) posto(s).

Tabela 8 - Percepção Acerca do Comportamento de Compra dos Clientes.

(Continua)

\begin{tabular}{|c|c|c|c|c|}
\hline Afirmativas & $\begin{array}{c}\text { Média } \\
\text { Inferior }\end{array}$ & Média & $\begin{array}{c}\text { Média } \\
\text { Superior }\end{array}$ & $\begin{array}{l}\text { Desvio } \\
\text { padrão }\end{array}$ \\
\hline $\begin{array}{l}\text { Você conhece os problemas que uma gasolina de má qualidade pode } \\
\text { trazer para o seu automóvel }\end{array}$ & 7,09 & 7,44 & 7,79 & 2,38 \\
\hline $\begin{array}{l}\text { A bandeira de um posto de gasolina é um atributo que você considera } \\
\text { importante }\end{array}$ & 6,65 & 7,00 & 7,35 & 2,89 \\
\hline Gostaria de ser atendido por mulheres & 5,79 & 6,14 & 6,49 & 2,66 \\
\hline $\begin{array}{l}\text { A possibilidade de comprar uma gasolina adulterada é maior se o seu } \\
\text { preço é baixo }\end{array}$ & 5,39 & 5,74 & 6,09 & 3,04 \\
\hline $\begin{array}{l}\text { Na estrada, você escolhe o posto de forma mais cautelosa do que } \\
\text { quando você está na cidade }\end{array}$ & 5,28 & 5,63 & 5,98 & 3,16 \\
\hline Você participa das promoções feitas pelos postos & 4,89 & 5,24 & 5,59 & 3,05 \\
\hline $\begin{array}{l}\text { Você conhece o programa de qualidade de combustíveis realizado } \\
\text { pela bandeira do posto }\end{array}$ & 4,46 & 4,81 & 5,16 & 3,08 \\
\hline $\begin{array}{l}\text { Quando você abastece num posto pela primeira vez, você se sente } \\
\text { desconfortável }\end{array}$ & 4,14 & 4,49 & 4,84 & 2,83 \\
\hline $\begin{array}{l}\text { O preço da gasolina é um indicador de que a gasolina é de boa } \\
\text { qualidade ou não }\end{array}$ & 3,91 & 4,26 & 4,61 & 2,73 \\
\hline
\end{tabular}


Tabela 8 - Percepção Acerca do Comportamento de Compra dos Clientes.

(Conclusão)

\begin{tabular}{lcccc}
\hline $\begin{array}{l}\text { Você coloca a mesma quantidade de gasolina quando abastece em um } \\
\text { posto desconhecido }\end{array}$ & 3,50 & 3,85 & 4,20 & 3,09 \\
Você é influenciado por outras pessoas em relação a compra de & 3,26 & 3,61 & 3,96 & 3,04 \\
gasolina & & & & \\
As mulheres são frágeis para trabalhar em um posto de gasolina & 2,69 & 3,04 & 3,39 & 2,57 \\
Você abastece sempre no mesmo horário & 2,62 & 2,97 & 3,32 & 2,53 \\
As mulheres não possuem o conhecimento necessário para o & 2,41 & 2,76 & 3,11 & 2,50 \\
atendimento em um posto de gasolina & & & & \\
O trabalho de atendimento em um posto deve ser feito só por homens & 2,26 & 2,61 & 2,96 & 2,41 \\
Você abastece sempre no mesmo dia da semana & 2,20 & 2,55 & 2,90 & 2,44 \\
\hline
\end{tabular}

Em relação ao trabalho feminino, observa-se que o mesmo tende a ser bem aceito pelas pessoas. Os resultados apontam que os consumidores gostariam de ser atendidos por mulheres, que esse serviço não precisa ser realizado necessariamente por homens, e que as mulheres possuem capacidade técnica para realizar esse serviço e não são frágeis para ele.

Outro ponto que pode ser identificado diz respeito ao comportamento de compra. Os respondentes não concordam com as afirmativas de que abastecem sempre no mesmo dia da semana ou no mesmo horário. Isso é um indicativo de que essa compra é mais por impulso do que planejada. Em geral participam das promoções feitas pelos postos de combustíveis e consideram que a bandeira dos mesmos é um item importante. Existe uma pequena tendência em acreditarem que conhecem os programas de qualidade dos combustíveis das distribuidoras. Além disso, não consideram que sofrem influência de outras pessoas.

A percepção de risco apresentou algumas das questões com o maior desvio-padrão. Isso é um indicativo de que existe uma maior divergência em relação a esse tópico, sendo que alguns consumidores provavelmente enxerguem um risco muito maior do que outros consumidores, o que gera padrões de concordância e de comportamento muito distintos. Existe uma tendência das pessoas desconfiarem de gasolina com preços mais baixos e de se sentirem desconfortáveis ao abastecer em um posto pela primeira vez. O comportamento de compra do consumidor também pode ser considerado diferente - mais cauteloso comparando-se a situação de abastecer na cidade ou na estrada (rodovia). Por fim, ao contrário do que foi apurado na pesquisa qualitativa, os consumidores acreditam que conhecem os malefícios que a gasolina adulterada pode trazer para o seu carro.

O próximo tópico a ser analisado diz respeito aos atributos mais importantes dos postos de combustíveis de acordo com os consumidores. 
Tabela 9 - Percepção da Importância dos Atributos dos Postos de Combustíveis Por Parte dos Consumidores

\begin{tabular}{l|cccc}
\hline \multicolumn{1}{c|}{ Atributos } & $\begin{array}{c}\text { Média } \\
\text { Inferior }\end{array}$ & Média & $\begin{array}{c}\text { Média } \\
\text { Superior }\end{array}$ & $\begin{array}{c}\text { Desvio } \\
\text { padrão }\end{array}$ \\
\hline A qualidade do combustível vendido & 7,96 & 8,31 & 8,66 & 1,79 \\
A rapidez no ato de abastecer o automóvel & 7,42 & 7,77 & 8,12 & 1,98 \\
A aparência do posto de combustível & 7,32 & 7,67 & 8,02 & 2,07 \\
A localização do posto de combustível & 7,17 & 7,52 & 7,87 & 2,17 \\
Aos preços praticados pelo posto de combustível & 6,90 & 7,25 & 7,60 & 2,32 \\
As formas de pagamento disponíveis no posto de combustível & 6,36 & 6,71 & 7,06 & 2,77 \\
A existência de uma loja de conveniência & 5,83 & 6,18 & 6,53 & 2,80 \\
\hline
\end{tabular}

Observando-se a tabela 9 acima, de uma forma em geral, todos os atributos que constam nessa pesquisa são considerados importantes pelos clientes. Contudo, aqueles considerados mais importantes são a qualidade do produto, a rapidez, aparência e localização dos postos de gasolina. Os itens relacionados a dinheiro como preço e formas de pagamento, apesar de serem considerados importantes, obtiveram as menores médias.

Em relação ao comportamento dos consumidores, os resultados da pesquisa quantitativa foram coerentes com os resultados da pesquisa qualitativa. A grande maioria dos respondentes já comprou em lojas de conveniência localizadas em postos de combustíveis, com $80 \%$ do total. Além disso, a maioria nunca comprovou a qualidade da gasolina no posto de gasolina no momento da compra - cerca de $76,8 \%$ do total - sendo que $57 \%$ dos entrevistados tinham conhecimento do seu direito de pedir para a realização do teste.

Por fim, a grande maioria dos consumidores abastece em um ou dois postos de gasolina - 71,9\% do total - e aqueles que abastecem somente no mesmo posto são $25,1 \%$. Os principais motivos são o de que as pessoas já têm o hábito de abastecer em determinado posto, seguido daquelas pessoas que analisam as opções e acreditam que fazem uma boa compra, com $41,1 \%$ e $30,5 \%$ do total. A freqüência de abastecimento é variável, mas os dois maiores grupos são aqueles que abastecem uma vez por semana (33,5\% do total) e aqueles que abastecem de duas a três vezes por mês (31,4\% do total). A quantidade de gasolina adquirida varia bastante sendo que aqueles que colocam entre 21 e 30 litros no tanque formam o maior grupo (24,1\% do total), seguidos pelos que colocam entre 11 e 20 litros $(22,4 \%)$.

\section{ANÁLISE DA DIFERENÇA ENTRE HOMENS E MULHERES}

Para verificar se as diferenças observadas nas médias entre homens e mulheres são estatisticamente significativas foram realizados testes t. Para Pestana e Gageiro ( 2000 ), 
quando deseja-se comparar as diferenças entre médias observadas de uma variável quantitativa em um ou em dois grupos, pode-se utilizar os testes t. Segundo Malhotra (2001), o teste t é o mais comum quando se deseja avaliar hipóteses relacionadas ao valores médios de uma variável. Os resultados obtidos em relação às questões que avaliam as mulheres atuando como frentistas em postos de gasolina estão sumarizados na tabela abaixo.

Tabela 10 - Teste $\mathrm{T}$ Para Homens e Mulheres Relacionado ao Fato das Mulheres Trabalharem em Postos de Combustíveis.

\begin{tabular}{|c|c|c|c|c|c|c|}
\hline \multirow{2}{*}{\multicolumn{2}{|c|}{ Variável / Hipótese }} & \multicolumn{2}{|c|}{$\begin{array}{l}\text { Teste de Levene } \\
\text { para igualdade de }\end{array}$} & \multicolumn{3}{|c|}{$\begin{array}{c}\text { Teste-t para igualdade de } \\
\text { médias }\end{array}$} \\
\hline & & $\mathrm{F}$ & Sig. & $\mathrm{T}$ & Sig. & $\begin{array}{l}\text { Diferença } \\
\text { das médias }\end{array}$ \\
\hline $\begin{array}{l}\text { O trabalho de atendimento em um } \\
\text { posto deve ser feito só por homens. }\end{array}$ & $\begin{array}{l}\text { Igualdade de variâncias } \\
\text { assumida }\end{array}$ & , 105 & ,746 & ,212 &, 832 & $6,19 \mathrm{E}-02$ \\
\hline & $\begin{array}{l}\text { Igualdade de variâncias } \\
\text { não assumida }\end{array}$ & & & ,217 & ,829 & $6,19 \mathrm{E}-02$ \\
\hline $\begin{array}{c}\text { Gostaria de ser atendido por } \\
\text { mulheres }\end{array}$ & $\begin{array}{l}\text { Igualdade de variâncias } \\
\text { assumida }\end{array}$ & 1,185 & 277 & 3,409 &, 001 & 1,10 \\
\hline & $\begin{array}{l}\text { Igualdade de variâncias } \\
\text { não assumida }\end{array}$ & & & 3,342 & ,001 & 1,10 \\
\hline $\begin{array}{c}\text { As mulheres não possuem o } \\
\text { conhecimento necessário para o }\end{array}$ & $\begin{array}{l}\text { Igualdade de variâncias } \\
\text { assumida }\end{array}$ & ,788 &, 375 & $-1,047$ & ,296 &,- 32 \\
\hline $\begin{array}{l}\text { atendimento em um posto de } \\
\text { gasolina. }\end{array}$ & $\begin{array}{l}\text { Igualdade de variâncias } \\
\text { não assumida }\end{array}$ & & & $-1,030$ &, 305 &,- 32 \\
\hline $\begin{array}{l}\text { As mulheres são frágeis para } \\
\text { trabalhar em um posto de gasolina. }\end{array}$ & $\begin{array}{l}\text { Igualdade de variâncias } \\
\text { assumida }\end{array}$ & 1,146 & ,285 &,- 924 &, 356 &,- 29 \\
\hline & $\begin{array}{l}\text { Igualdade de variâncias } \\
\text { não assumida }\end{array}$ & & &,- 913 &, 363 &,- 29 \\
\hline
\end{tabular}

Verifica-se que em todas as afirmativas não se rejeita a hipótese de igualdade de variâncias, o que significa que para todas as afirmativas, a linha de igualdade de variâncias assumida - primeira linha de cada variável - deverá ser utilizada para a análise do teste t. Assim, de acordo com os resultados apresentados, é possível concluir que somente a afirmativa "Gostaria de ser atendido por mulheres" apresentou diferença estatisticamente significativa. Todas as outras afirmativas analisadas não apresentaram diferença estatisticamente significativa entre homens e mulheres.

Em relação aos atributos considerados mais importantes em um posto de gasolina, também foi realizado um teste t para verificar se as diferenças observadas entre homens e mulheres também são estatisticamente significativas. Ao se confrontar os resultados obtidos 
nas amostras total, masculina e feminina, percebe-se que o atributo mais importante (qualidade do combustível vendido) e os três menos importantes (em ordem decrescente de importância: preços praticados, formas de pagamento e existência de loja de conveniência) ocupam a mesma posição quando se organizam os atributos em ordem decrescente de importância. Para os homens, aparência, rapidez e localização são os atributos mais importantes depois da qualidade do combustível vendido. Já para as mulheres, rapidez, localização e aparência são os atributos que ocupam esta posição. Conclui-se que mulheres e homens apresentam percepções de importância mais homogêneas em relação aos atributos menos importantes dos postos. Quanto aos atributos mais importantes - exceto a qualidade do combustível vendido -, homens e mulheres apresentam percepções mais heterogêneas.

Tabela 11 - Teste T Para Homens e Mulheres Relacionado aos Atributos Mais Importantes dos Postos de Combustível.

\begin{tabular}{|c|c|c|c|c|c|c|}
\hline \multicolumn{2}{|c|}{ Variável / Hipótese } & \multicolumn{2}{|c|}{$\begin{array}{c}\text { Teste de Levene para } \\
\text { igualdade de } \\
\text { variâncias }\end{array}$} & \multicolumn{3}{|c|}{$\begin{array}{l}\text { Teste-t para igualdade de } \\
\text { médias }\end{array}$} \\
\hline & & $\mathrm{F}$ & Sig. & $\mathrm{t}$ & Sig. & $\begin{array}{l}\text { Diferença } \\
\text { média }\end{array}$ \\
\hline $\begin{array}{l}\text { As formas de pagamento } \\
\text { disponíveis no posto de }\end{array}$ & $\begin{array}{c}\text { Igualdade de variâncias } \\
\text { assumida }\end{array}$ & 2,950 & 087 & $-1,919$ & 056 &,- 64 \\
\hline combustível & $\begin{array}{l}\text { Igualdade de variâncias } \\
\text { não assumida }\end{array}$ & & & $-1,983$ & ,049 &,- 64 \\
\hline $\begin{array}{l}\text { A rapidez no ato de } \\
\text { abastecer o automóvel }\end{array}$ & $\begin{array}{c}\text { Igualdade de variâncias } \\
\text { assumida }\end{array}$ & 1,956 & ,163 &,- 799 & ,425 &,- 19 \\
\hline & $\begin{array}{l}\text { Igualdade de variâncias } \\
\text { não assumida }\end{array}$ & & &,- 843 & ,401 &,- 19 \\
\hline $\begin{array}{l}\text { Aos preços praticados pelo } \\
\text { posto de combustível }\end{array}$ & $\begin{array}{c}\text { Igualdade de variâncias } \\
\text { assumida }\end{array}$ & ,006 & ,938 &,- 519 & ,604 &,- 14 \\
\hline & $\begin{array}{l}\text { Igualdade de variâncias } \\
\text { não assumida }\end{array}$ & & &,- 509 & ,612 &,- 14 \\
\hline $\begin{array}{l}\text { A existência de uma loja de } \\
\text { conveniência }\end{array}$ & $\begin{array}{c}\text { Igualdade de variâncias } \\
\text { assumida }\end{array}$ &, 232 & ,630 &,- 338 & ,736 &,- 12 \\
\hline & $\begin{array}{l}\text { Igualdade de variâncias } \\
\text { não assumida }\end{array}$ & & &,- 340 &, 734 &,- 12 \\
\hline $\begin{array}{l}\text { A localização do posto de } \\
\text { combustível }\end{array}$ & $\begin{array}{c}\text { Igualdade de variâncias } \\
\text { assumida }\end{array}$ & 1,699 & ,193 & $-1,229$ &, 220 &,- 32 \\
\hline & $\begin{array}{l}\text { Igualdade de variâncias } \\
\text { não assumida }\end{array}$ & & & $-1,296$ & ,197 &,- 32 \\
\hline $\begin{array}{c}\text { A aparência do posto de } \\
\text { combustível }\end{array}$ & $\begin{array}{c}\text { Igualdade de variâncias } \\
\text { assumida }\end{array}$ & 000 & ,987 & 1,088 &, 277 &, 27 \\
\hline & $\begin{array}{l}\text { Igualdade de variâncias } \\
\text { não assumida }\end{array}$ & & & 1,126 & ,262 &, 27 \\
\hline $\begin{array}{l}\text { A qualidade do combustível } \\
\text { vendido }\end{array}$ & $\begin{array}{c}\text { Igualdade de variâncias } \\
\text { assumida }\end{array}$ & 8,173 &, 004 & $-1,513$ &, 131 &,- 33 \\
\hline & $\begin{array}{c}\text { Igualdade de variâncias } \\
\text { não assumida }\end{array}$ & & & $-1,863$ &, 064 &,- 33 \\
\hline
\end{tabular}

Assim, de acordo com os resultados e as verificações acima, é possível concluir que nenhum atributo apresentou diferença estatisticamente significativa em suas médias para homens e mulheres 


\section{CONSIDERAÇÕES FINAIS}

Em termos práticos, ao se analisar os atributos mais valorizados pelos consumidores em relação aos postos de combustíveis, verifica-se que os atributos que os consumidores consideram mais importantes estão relacionados à tríade "qualidade-rapidez-aparência" caracteriza os atributos mais importantes para a amostra - apesar de estatisticamente não significativas, mesmo com as pequenas diferenças observadas entre homens e mulheres.

Os resultados obtidos nesta pesquisa são diferentes daqueles encontrados por Patrício (2003). Em sua pesquisa, ele identificou que os atributos mais importantes são respectivamente, localização do posto, educação do frentista e qualidade dos serviços oferecidos no posto. Aqueles considerados menos importantes pelos consumidores, foram descritos respectivamente: as condições de pagamento oferecidas no posto, variedade dos produtos e velocidade no atendimento.

Entre os fatores considerados mais importantes pelos gestores de postos de combustíveis para aumentar a sua competitividade estão o atendimento rápido e cordial dos frentistas, localização e serviço de troca de óleo, respectivamente (FERNANDES, 2001).

Essas informações são muito importantes para a administração e estratégia de marketing - os famosos 4P’s de McCarthy descritos na década de 1960 - de todos aqueles envolvidos no setor de combustíveis. Em relação ao produto e ao serviço, é necessário que apresentem os atributos considerados mais importantes pelos consumidores. Assim, diversas decisões relacionadas à gestão de produtos e serviços têm de considerar que o comportamento dos consumidores - principalmente o processo de decisão de compra e escolha de marcas - é fortemente afetado pela presença e pela quantidade desses atributos considerados mais importantes. Assim, a qualidade do combustível é um fator primordial para a gestão de produto e o atendimento, rapidez, higiene e limpeza são fundamentais na gestão de serviços. Além disso, o design e projeto do posto de combustível devem ressaltar aqueles aspectos que mais contribuem para uma melhor aparência aos olhos dos clientes. A utilização de mulheres nas atividades de frentista em um posto de combustível foi aprovada pelos consumidores. Não se percebeu grandes variações em relação ao público feminino ou masculino - notadamente em relação às atividades desenvolvidas e nos riscos percebidos. Somente em relação ao fato de que gostaria de ser atendido por mulheres, observou-se uma diferença significativamente positiva entre homens e mulheres, de forma mais positiva para os primeiros. Todavia, como foi descrito no referencial teórico, a presença das mulheres no mercado automotivo é muito grande ( MICHELAZZO, 1998; MAIA, 2001 ) e obviamente novas pesquisas devem ser 
conduzidas para se descobrir diferenças entre homens e mulheres, com o intuito de se desenvolver novas estratégias mercadológicas.

Outro fator a ser ressaltado é a formação de preços que deve levar em consideração esse processo de escolha por parte do consumidor. Assim, os postos de combustíveis que apresentam em maior quantidade as características mais valorizadas pelos clientes poderão ser considerados produtos premium e dessa forma também ter preço premium. Apesar de o preço ter sido considerado um dos atributos menos importantes de acordo com os consumidores, é importante considerar estratégias de preço que valorizem a fidelização dos clientes. Além disso, é importante aproveitar as promoções, muitas desenvolvidas pelas maiores administradoras de combustíveis existentes no Brasil.

Como já foi descrito, a localização é um dos atributos mais importantes para os clientes e está relacionado "P de praça". Por conseguinte, é necessário priorizar a escolha do local onde o posto opera, considerando as regiões e o fluxo de tráfego para poder oferecer valor ao consumidor, cuja maioria vive em grandes centros urbanos, o que transforma o tempo em um fator cada vez mais escasso e valorizado pelos indivíduos.

Por último, mas não menos importante, o processo de comunicação deve enfatizar a qualidade e a garantia da gasolina que está sendo vendida, principalmente para aqueles que viajam bastante e nos períodos de férias escolares. Foi observado que os consumidores conhecem pouco a respeito dos programas de qualidade das distribuidoras de combustíveis. As distribuidoras de combustíveis, proprietárias de bandeiras, devem ressaltar a qualidade do produto que é oferecido nas rodovias brasileiras, em virtude de que muitos acreditam que a fiscalização não é tão eficiente nesses lugares quanto nas cidades. Isso é importante para que o consumidor tenha cada vez mais certeza da qualidade do produto que ele tanto valoriza. Além disso, o processo de comunicação deve ser capaz de enfatizar aspectos que valorizem o layout e a aparência do posto, de forma a aumentar a sensação de confiança do consumidor. Não foram observadas grandes diferenças em relação ao gênero. Isso pode facilitar o processo de comunicação, pois, os mesmos apelos de posicionamento e de vendas podem ser usados tanto para homens, quanto para mulheres.

Outra estratégia de marketing se atém a programas de marketing de relacionamento. Como a tendência dos clientes é a de "naturalmente" abastecerem em poucos postos de gasolina, iniciativas e projetos de fidelização provavelmente possuem maior possibilidade de alcançarem os seus objetivos e apresentarem resultados. É importante ressaltar que determinados clientes possuem grande valor de "tempo de vida" com cliente em virtude de serem jovens e as pessoas - em geral - somente param de comprar gasolina quando morrem ou quando estão idosas demais para dirigir um automóvel. Em relação ao comportamento dos 
consumidores, o fato de que a maioria das pessoas sabe que podem pedir a realização de um teste para verificar a qualidade da gasolina e que poucos solicitam esse procedimento, pode se dever ao fato de que a rapidez é o segundo atributo considerado mais importante pelos clientes, aliado ao fato de que muitos sempre abastecem no mesmo posto e o carro não apresentar problemas, acreditam que a gasolina é de boa qualidade.

Em termos teóricos, esse trabalho apresenta resultados interessantes e promissores. Em primeiro lugar, os fatores descobertos a partir desse estudo são consistentes e parecem realmente enfatizar determinados aspectos relevantes para os consumidores em relação à gasolina, notadamente em relação ao comportamento habitual. O próximo passo da pesquisa seria uma análise fatorial exploratória e depois confirmatória com o intuito de diminuir o número de fatores considerado pelos consumidores e construção de uma escala de avaliação da qualidade percebida do serviço oferecido. A partir daí, poderia trabalhar-se a validação dessa escala.

Ainda em termos teóricos, é interessante observar que o aprendizado pelo qual a maioria dos consumidores passa ao começar a abastecer em um posto de combustível, nunca pedindo o teste de qualidade e acreditando que a gasolina é de qualidade é o condicionamento instrumental, onde - nessa situação - se o carro nunca apresenta defeitos, ele volta ao posto para colocar mais gasolina. É importante ressaltar ainda, que é possível concluir que a escolha de um posto de combustível depende de uma série de atributos combinados entre si.

A principal limitação da presente pesquisa refere-se ao caráter não probabilístico do método de amostragem utilizado. Assim sendo, os resultados obtidos não poderão ser generalizados para a população. Sugere-se, portanto, que sejam conduzidas novas pesquisas, com base em amostras aleatórias. Além disso, foi realizado um corte transversal, ou seja, os dados foram coletados apenas uma vez no tempo, retratando uma situação momentânea que pode se modificar ao longo do tempo.

Considerando-se a carência de pesquisas acadêmicas sobre os consumidores de gasolina e de combustíveis em geral, sugere-se que sejam conduzidas novas pesquisas no país, de acordo com as regiões, envolvendo os hábitos de consumo, os atributos os consumidores estariam dispostos a pagar um valor extra, a satisfação dos consumidores e a imagem das marcas. Tais pesquisas poderão contribuir com a criação de estratégias mais adequadas por parte dos participantes da indústria de combustíveis. 


\section{REFERÊNCIAS}

AAKER, D.; KUMBAR, V.; DAY, G. S. Pesquisa de marketing. São Paulo: Atlas, 2001.

AJZEN, I. Nature and operation of attitudes. Annual Review of Psychology, v. 52, p. 27-58, 2001.

AJZEN, I.; FISHBEIN, M. Attitudes and the attitude-behavior relation: Reasoned and automatic processes. In: STROEBE, W.; HEWSTONE, M. (Eds.), European Review of Social Psychology. John Wiley ; Sons. p. 1-33, 2000.

ANP - Associação Nacional do Petróleo. Boletim de Qualidade dos Combustíveis Automotivos. Atualizado em abril de 2009. Disponível em: <http://www.anp.org.br> Acesso em: 04 abr. 2009.

BARTOS, R. Segmentos do mercado feminino. HSM Management, São Paulo, n.9, pp. 1216, jul/ago. 1998.

BENNETT, P. D.; KASSARJIAN, H. H. O Comportamento do consumidor. São Paulo: Atlas, 1975.

CANTON, A. W. P.; GRISI, C. C.; SANTOS, R. C. Avaliando os níveis de envolvimento dos consumidores. IN: ENANPAD - ENCONTRO ANUAL DA ASSOCIAÇÃO NACIONAL DE PÓS-GRADUAÇÃO EM ADMINISTRAÇÃO, 13. Anais... Belo Horizonte, set. 1989, p. 741-752.

ENGEL, J. F.; BLACKWELL, R. D.; MINIARD, P. W. Comportamento do consumidor. São Paulo: Pioneira Thomson Learning, 2005.

FERNANDES, A. W. A. Análise sobre a prestação de serviços nos postos de revenda de combustíveis nos últimos anos. São Paulo, 2001. 110f. Dissertação (Mestrado em Energia). Universidade de São Paulo.

FISHBEIN, M.; AJZEN, I. Attitudes and opinions. Annual Review of Psychology, v. 23, p. 487- 544, 1972.

HAIR JR., J. F.et al. Multivariate data analysis. New Jersey: Prentice Hall, 1998.

HAWKINS, Del I.; MOTHERSBAUGH, D. L.; BEST, R. J. Comportamento do

Consumidor: construindo a estratégia de marketing. Rio de Janeiro: Elsevier, 2007.

KARSAKLIAN, E. Comportamento do consumidor. São Paulo: Atlas, 2000.

KOTLER, P.; KELLER, K. Administração de marketing. São Paulo: Makron Books, 2006.

LAWSON, R. W. Consumer Behaviour. In: BAKER, M. J. (org.). Marketing theory: a student book. Tunbridge Wells, Kent: Thomson Learning, 2000.

LIMA, A. L. de S. Identificação dos valores do consumidor na decisão de compra em situação de baixo envolvimento. 2008. 132f. Dissertação (Mestrado de Administração e Desenvolvimento Empresarial) Universidade Estácio de Sá. Rio de Janeiro. 
MAIA, R. Montadoras se adequam ao gosto feminino. Pampulha, Caderno Carro;Cia. Belo Horizonte, 15 a 21 dez. 2001. p.1.

MALHOTRA, N. K. Pesquisa de marketing: uma orientação aplicada. Porto Alegre: Bookman, 2001.

MARCONI, M. de A.; LAKATOS, E.M. Técnicas de pesquisa. São Paulo: Atlas, 1986.

MICHELAZZO, L. A. Feminino e sem frescura. O Globo, Caderno Carro Etc. Rio de Janeiro, 21 jan.1998. p.1.

MOWEN, J. C.; MINOR, M. S. Comportamento do consumidor. São Paulo: Prentice Hall, 2003.

PACHAURI, M. Consumer behaviour: a literature review. The Marketing Review, v. 2, p. 319-355, 2002.

PATRÍCIO, G. de C. Preferência do consumidor em postos de gasolina: um levantamento no Posto Água Dourada. 203. 155f. Dissertação (Mestrado em Administração). Universidade Federal de Santa Catarina. Florianópolis.

PESTANA, J. N.; GAGEIRO, M. H. Análise de dados para ciências sociais: a complementariedade do SPSS. Lisboa: Sílabo, 2000.

PETERS, T. O Poder das mulheres. HSM Management, São Paulo, n.7, pp. 14-18, mar/abr. 1998.

NEWTON, R. R.; RUDESTAM, K.1 E. Your statistical consultant: answer to your research: data analysis questions. Sage-UK, 1999.

SANTOS, Z. M. C. dos. Qualidade e valor percebido: a influência da reputação da marca nos postos de gasolina em Volta Redonda. 2007. 120f. Dissertação (Mestrado de Administração e Desenvolvimento Empresarial) Universidade Estácio de Sá. Rio de Janeiro.

SCHEWE, C. D.; SMITH, R. M. Marketing: conceitos, casos e aplicações. São Paulo: McGraw-Hill do Brasil, 1982.

SHAPIRO, B. A Psicologia da fixação de preços. São Paulo: Nova Cultural, 1986. (Coleção Harvard de Administração, v.19).

SIMONSON, I. et al. Consumer Research: In Search of Identity. Annual Review Psychology, v. 52, p. 249-275, 2001.

SINDICOM - Sindicato Nacional das Empresas Distribuidoras de Combustíveis e Lubrificantes. Disponível em: <http://www.sindicom.com.br> Acesso em: 04 abr. 2009.

TABACHINIK, B. G.; FIDELL, L. S. Using Multivariate Statistics. 4 ed. New York: HarperCollins, 2001. 